\title{
Physico-Chemical Characteristics of Gushing Water Aquifers in the Coastal Sedimentary Basin of Benin (West Africa)
}

\author{
Prudence Mahutondji Dossou ${ }^{1,2^{*}}$, Crépin Zevounou2 ${ }^{2}$, Abdoukarim Alassane ${ }^{3}$, Christophe Kaki², \\ Moussa Boukariं ${ }^{3}$, Daouda Mama ${ }^{3}$
}

${ }^{1}$ Chaire Internationale en Physique, Mathématique et Applications (CIPMA-Chaire UNESCO), Université d'Abomey-Calavi, Abomey-Calavi, Bénin

${ }^{2}$ Laboratoire de Géologie, Mines et Environnement, Faculté des Sciences et Techniques, Université d’Abomey-Calavi, Abomey-Calavi, Bénin

${ }^{3}$ Laboratoire d'Hydrologie Appliquée (LHA), Institut National de l'Eau (INE), Université d'Abomey-Calavi, Abomey-Calavi, Bénin

Email: *prudencedossou12@gmail.com

How to cite this paper: Dossou, P. M., Zevounou, C., Alassane, A., Kaki, C., Boukari, M., \& Mama, D. (2021). Physico-Chemical Characteristics of Gushing Water Aquifers in the Coastal Sedimentary Basin of Benin (West Africa). Journal of Geoscience and Environment Protection, 9, 149-163. https://doi.org/10.4236/gep.2021.97010

Received: May 30, 2021

Accepted: July 25, 2021

Published: July 28, 2021

Copyright $\odot 2021$ by author(s) and Scientific Research Publishing Inc. This work is licensed under the Creative Commons Attribution International License (CC BY 4.0).

http://creativecommons.org/licenses/by/4.0/

\begin{abstract}
The coastal sedimentary basin in southern Benin consists of monoclinal layers divided into two plateau zones (North and South) which are separated by a longitudinal depression ESE-WNW. The valleys of the main N-S-oriented rivers (Ouémé, Couffo and Mono) set the bondaries of the different plateau of the BSC (Coastal Sedimentary Basin). The present study, based on geology, hydrochemistry, temperature and log data available on boreholes, makes a physico-chemical characterization of the waters of the gushing aquifers of the coastal sedimentary basin of Benin. The gushing water boreholes are shared between the valleys of the main rivers of the BSC. Some of these boreholes are thermal with a water temperature between 38 and 69 degrees Celsius. The hydrogeological correlations established in the BSC in accordance to the NorthSouth direction in the valleys of the main streams (Couffo and Ouémé) reveal that the captured aquifers are sands, marls and limestones that respond either in major discordance (northern zone) or above the sedimentation gaps (southern zone). Chemical analyses have shown that gushing thermal waters are mineralized in the south with a neutral to basic $\mathrm{pH}$ and are highly concentrated with bicarbonate, calcium and magnesium ions. In the North, on the other hand, thermal waters are acidic with a $\mathrm{pH}$ ranging from 4.8 to 5.9. The acidic nature of the northern waters is influenced by the crystalline base while the southern neutral to basic waters are influenced by the lithological nature (limestone and marl) of the aquifer. The random distribution of thermal water boreholes in the valleys of the main BSC streams is believed to be related to tectonic events.
\end{abstract}




\section{Keywords}

Gushing Aquifers, Thermal Water, Physico-Chemical, BSC

\section{Introduction}

Groundwater is a valuable asset for human consumption and other multiple uses; this is especially true when groundwater is thermal (IEA, 2011). Also, they are easily accessible when they are gushing (Adissin et al., 2019). Indeed, gushing water points are particularly appealing because households access them without spending energy in pumping. Moreover, the permanent flow of these waters promotes their multiple uses for the development of small-scale agriculture (market gardening, irrigation) and livestock (Ahossi, 2020). As thermal water, they also serve other purposes such as energy supply and sanitary treatment (Kapasa, 2014).

In Benin, in the coastal sedimentary basin, boreholes have captured gushing water aquifers, sometimes thermal water in some communities (Boukari \& Alassane, 2007). Besides the aforementioned uses, thermal waters are used for palm oil processing activities. Among the multitude of gushing water boreholes, one can notice an unexplained distribution of gushing and thermal water points to this day.

This study aims to characterize gushing water aquifers with an emphasis on the origin of the distribution of thermal abnormalities.

\section{Presentation of the Study Area}

\subsection{Localization}

The territorial scope of the coastal sedimentary basin of Benin encompasses the localities situated in the latitudes $7^{\circ} 36^{\prime}$ and $7^{\circ} 12^{\prime}$ North and longitudes $1^{\circ} 36^{\prime}$ and $2^{\circ} 48^{\prime}$ East (Figure 1). The total area is about $11,200 \mathrm{~km}^{2}$ (Boukari, 2002). From administrative standpoint, it includes the entire Atlantic, Coastal, Mono, Ouémé, Plateau and part of the Zou and Couffo provinces.

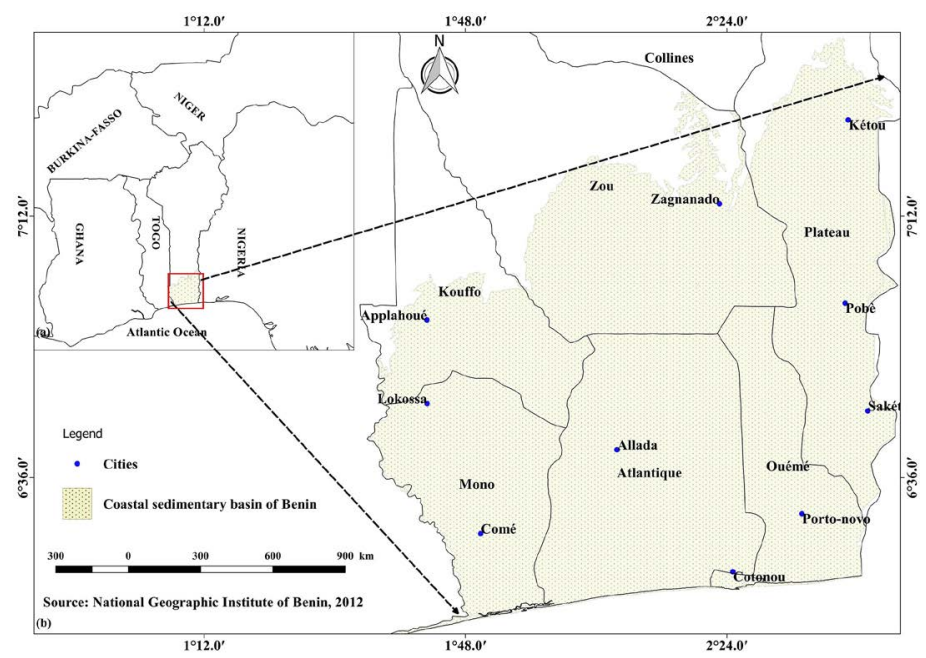

Figure 1. Location of the study area in Dahomey Bay. 


\subsection{Climate}

In Benin, the annual average temperatures range from 26.5 to 27.5 degrees Celsius depending on the region (Boukari, 2002). The relative humidity is very high everywhere during the rainy season ( $80 \%$ on average in July and September). This rate drops during the warmer season (mainly between January and February) to about $60 \%$ in the South (Le Barbé et al., 1993). The annual rainfall system to which the coastal sedimentary basin belongs is equatorial (or sub-equatorial) and consists of four seasons (a large warm season from November to April, a large rainy season from April to July, a small warm season from July to September, and a small rainy season from September to November).

\subsection{Geomorphology}

The coastal sedimentary basin is located in the southern part of Benin and consists of sediments supported by a crystallophyllian base (Boukari, 2002). The morphology of the coastal sedimentary basin is characterized by two sets of plateaux arranged on either side of an ENE-WSW-oriented median depression, the Lama depression (Figure 2). The main rivers (Mono, Couffo and Ouémé) flow southward and form respectively the valleys of Mono, Couffo and Ouémé (Le Barbé et al., 1993).

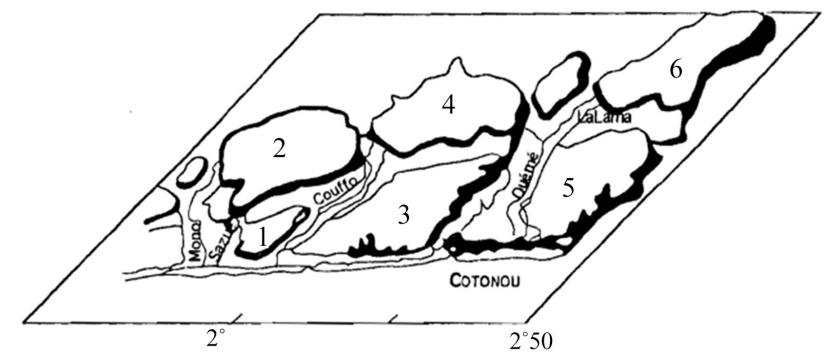

Figure 2. Geomorphological map of the coastal sedimentary basin of Benin (Slansky (1962) modified after IRB (1989), City by Boukari and Alassane (2007)): Comé plateau; 2: Aplahoué plateau; 3: Allada plateau; 4: Abomey plateau; 5: Sakété plateau; 6: Kétou plateau.

\subsection{Geology}

The geology of the Coastal Sedimentary Basin of Benin is the same as the Bay of Dahomey (Figure 3), which extends from Ghana on the west, and to Nigeria on the east (Slansky, 1962). These deposits have a monoclinal structure characterized by differential subsidence increasing toward the SSE (Dray et al., 1989). Based on lithological and sedimentological landmarks that support successive variations in sea level, eight stratigraphic units have been enumerated (Figure 3) from the Turonian-Coniacien (Unit I) to the Quaternary (Unit VIII), (Slansky, 1962; Lang \& Houessou, 1978; Zevounou, 1992; Oyede et al., 2006; Zevounou et al., 2012): Unit I (Turonian-Coniacien): quartz sands with pebbles, intercalations of lignitous and marno-limestone levels; Unit II (Maastrichtian, Lower and Middle Paleocene): sands, argillites, marls, limestone; Units III to IV (Upper Pa- 
leocene, Middle Eocene): Kaolinitic clay, argillites, sometimes marl; Units V to VII (Mio-Pliocene, "Continental Terminal"): quartz sands, gravel; Unit VIII (Quaternary): sands and argillites.



Figure 3. Geological map of the Benin County Sedimentary Basin (extracted from geological sheets at 1/200,000 Lokossa-Porto Novo and Abomey-Zangnanado (IRB, 1989)).

\subsection{Hydrogeology}

By their lithological nature (Figure 3), the geological formations of the coastal sedimentary basin of Benin are grouped into four hydrogeological reservoirs. From north to south, there are listed as follow:

- The Upper Cretaceous sand aquifer or Unit I (Figure 3). It can reach up to 150 meters of thickness but remains mostly less accessible to the south of the basin due to its rapid sinking (Boukari, 2005). While its nappe is free in the north of the depression of Lama, where it emerges, it is captivated, in the South, under the argillites and the marls of both Maastrichtian and Eocene, where it sinks rapidly.

- The aquifer of the Paleocene limestone or IIb unit is essentially captivated under the argillites and marls of the Upper Paleocene and the Lower and Middle Eocene (Figure 3). Its thickness varies from a few meters to a maximum of thirty meters (Boukari, 2005). It is sometimes outcropping or suboutcropping inside the Lama depression, then rapidly sinks southward and gets captivated under the clays in the valleys of the main BSC streams (Boukari \& Alassane, 2007).

- The sand aquifer of the Upper Miocene-Pliocene or Units VI and VII (Figure 3). Its maximum thickness is generally around 120 meters and its nappe is usually free. Moreover, it is superficially subdivided into three hydrogeologi- 
cal units morphologically represented by the southern plateaus of the basin (Boukari, 2005).

- The Quaternary aquifers or Unit VIII are represented by the aquifers of the coastal sands, on one hand, and those of the alluvial sands on the other (Figure 3). Their maximum thicknesses are around 20 meters (Boukari \& Alassane, 2007). In the alluvial valleys of the Mono River and especially the complex Oueme-Lac Nokoué, aquifers are often loaded under more or less superficial argillites with frequent phenomena of gushing artesian.

\section{Material and Methods}

The methodological structuring of this study is described in three phases: the collection of existing data; on-site work and processing and analysis of the data obtained.

\subsection{Material}

The collected data relate to the lithology of boreholes that capture the gushing water aquifers of the Upper Cretaceous and Paleocene, especially those with thermal water. The topographic sheets, the geological sheets (Abomey-Zangnanado, Lokossa-Porto Novo) made at a scale of 1/200,000 were also collated. The temperature of the borehole waters that capture the Cretaceous, Paleocene and Miocene-Pliocene aquifers has been collated. These data are obtained from the structures responsible for water management (General Directorate of Water, Department of Water) and the Benin Office of Geological and Mineral Research (OBRGM).

The on-site work is performed with the aim of mapping the geothermal abnormal points in the coastal sedimentary basin; therefore, a GPS has been used. The measurement of the physico-chemical parameters and the water sampling of the thermal boreholes allowed the geochemistry of the thermal anomaly zones to be highlighted. At each thermal water point encountered, the geographical coordinates are recorded along with $\mathrm{pH}$ and temperature values, conductivity and water collection.

\subsection{Data Analysis and Processing}

In order to better describe the geometry and structure of the gushing aquifers in the study area, two hydrogeological sections were performed along the northsouth oriented lines $\mathrm{AA}^{\prime}$ and $\mathrm{BB}^{\prime}$. Chemical analyses were performed on eight samples and were focused on some major water elements $\left(\mathrm{NH}_{4}^{+}, \mathrm{Ca}^{2+}, \mathrm{Mg}^{2+}\right.$, $\mathrm{HCO}_{3}^{-}$).

Temperature and depth data collected from the boreholes are entered into Surfer and QGIS to obtain maps of iso-depht and isotherms after validation with the coefficient of some statistical parameters such as the NASH and RSR coefficient of the Cretaceous, Paleocene and Neogene aquifers. Table 1 shows the characteristics of the fitted variograms. 
Table 1. Characteristics of variograms.

\begin{tabular}{|c|c|c|c|c|}
\hline Data & Aquifers & Model & NASH & RSR \\
\hline \multirow{4}{*}{ Depth } & Neogene (a) & & 0.78 & 0.50 \\
\hline & Paleogene (b) & & 0.80 & 0.40 \\
\hline & Cretaceous (c) & & 0.76 & 0.50 \\
\hline & & Power & & \\
\hline \multirow{3}{*}{ temperature } & Neogene (a') & & 0.84 & 0.39 \\
\hline & Paleogene (b') & & 0.81 & 0.42 \\
\hline & Cretaceous $\left(c^{\prime}\right)$ & & 0.79 & 0.51 \\
\hline
\end{tabular}

Figure 4 shows respectively the variograms of customized models of the depth and temperature of the Neogene (aa'), Paleocene (bb') and Cretaceous (cc') of the coastal sedimentary basin. One can notice upon observation of these figures (Figure 4) that the model passes through the majority of points. The interpolation method used is Kriging and the power model was chosen for the kriging. This model adjusted for the raw variogram allowed us to obtain depth and temperature values in areas where there are no measurements (Lawin, 2007). The expression of the variogram of the power model is:

$$
\gamma(h)=C_{0}+\left(\alpha-C_{0}\right) h^{\beta}
$$

with $\beta \in] 0,2\left[; C_{0}\right.$ petite; $h$ the distance

After the visual assessment of the overlay, the criteria of Nash (2) and RSR (3) allowed us to control the adjustment made so that the theoretical variogram better approaches the interesting part of the raw variogram (Figure 4). These criteria are defined as follows:

Nash (coefficient of Nash, NSE)

$$
\text { NSE }=1-\left[\frac{\sum_{i=1}^{n}\left(Y_{1}^{\text {obs }}-Y_{1}^{\text {sim }}\right)^{2}}{\sum_{i=1}^{n}\left(Y_{1}^{\text {obs }}-Y_{1}^{\text {mean }}\right)^{2}}\right]
$$

The adjustment is optimal when the Nash coefficient efficiency is maximum (close to 1 ).

RSR (standard observations deviation ratio)

$$
\mathrm{RSR}=\frac{\mathrm{RMSE}}{\operatorname{STDEV}_{\text {obs }}}=\frac{\left[\sqrt{\sum_{i=1}^{n}\left(Y_{1}^{\text {obs }}-Y_{1}^{\text {sim }}\right)^{2}}\right]}{\left[\sqrt{\sum_{i=1}^{n}\left(Y_{1}^{\text {obs }}-Y_{1}^{\text {mean }}\right)^{2}}\right]}
$$

The model is optimal when RSR is less or equal to 0.70 (Moriasi et al., 2007). This method allows us to identify the best set of parameters $\left(C_{0}, C\right.$ and a) that characterize the modeled variogram (Lawin, 2007). 

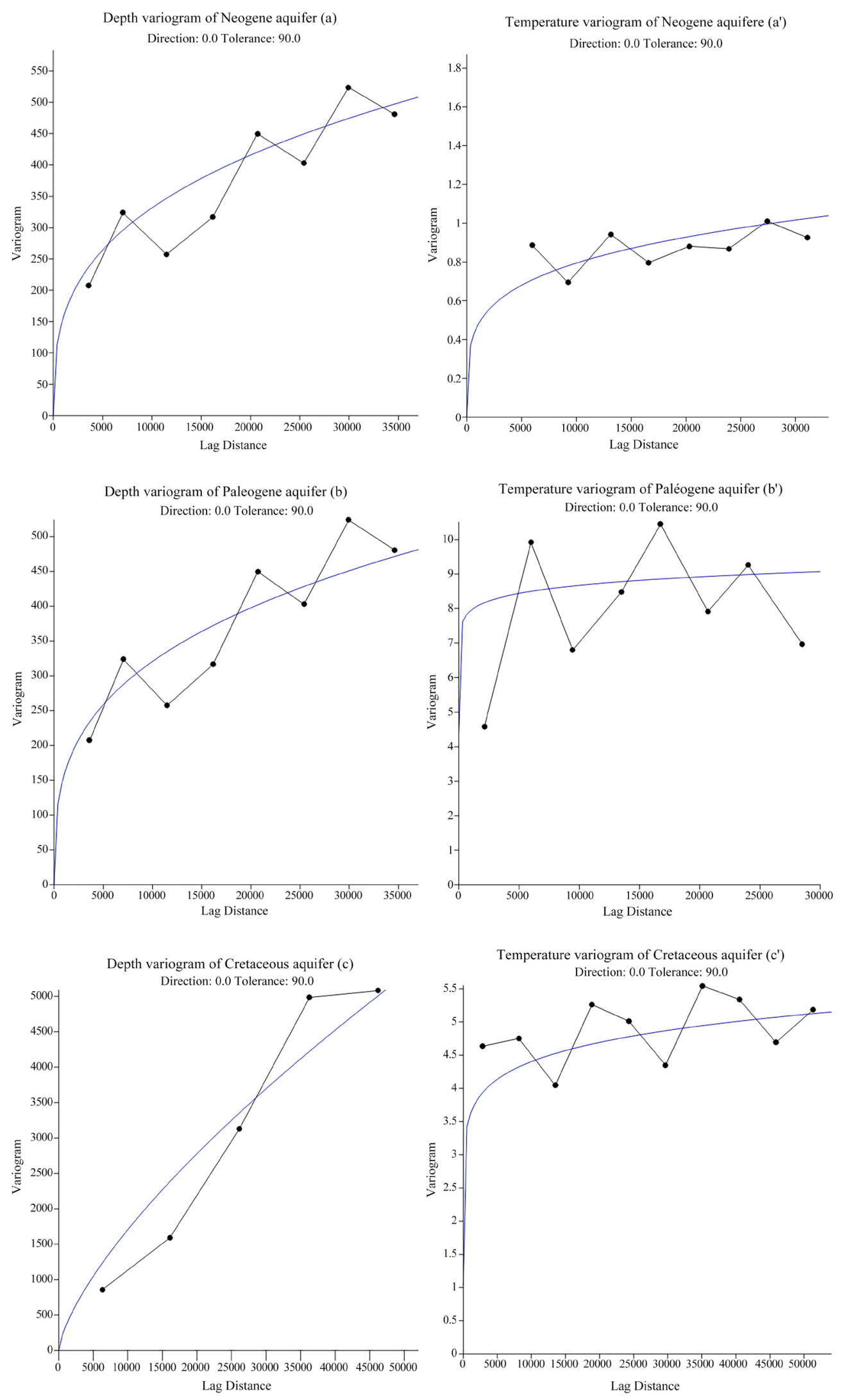

Figure 4. Avariogram of distances adjusted for depth ( $a, b$ and $c)$ and temperature (a', b' and $\left.c^{\prime}\right)$ of the BSC Neogen, Paleocene and Cretaceous aquifers. 


\section{Results}

\subsection{Distribution of Captured Aquifers and Depth Variation}

\subsubsection{Analysis of $A A^{\prime}$ and $B B^{\prime}$ Lithostratigraphic Sections}

The N-S lithostratigraphic correlations of section $\mathrm{AA}^{\prime}$ in the Ouéme river watershed reveal six facies (Figure 5). From top to bottom, these are clay or laterite, gravel, clay sand, limestone and sand. The summit formations are represented by clays or laterites in the works. In the northern part of the section, the base is represented by the Gneiss and is located at a depth of about 100 meters. The sandy layer is located at a depth of about 90 meters and gradually sinks toward the southern part of the section. The thermal water points captured the sands at an average depth of 160 meters to about 200 meters. The temperature of these waters is between 39 and 50 degrees Celsius (Sagon and Gohissanou, respectively). In the southern part of the section, at the localities of Ahitonou, the formations captured are limestones. The Ahitonou borehole captures these limestones at a depth of about 60 meters with a temperature of $41^{\circ} \mathrm{C}$ while at a few hundred meters away (Atchabita), the same limestones are captured at 200 meters with a temperature of $41^{\circ} \mathrm{C}$. The two boreholes are separated by the Zounvo river, which is a tributary stream of Ouémé river. This offset observed in the formations of these boreholes and the presence of the stream suggests that the area is crossed by faults. In the Southern part of the section, the limestones are located at a depth of more than 400 meters. Also, the thickness of the clays becomes consistent in this part of the section. Indeed, in the localities of Hetin-Sota, the limestones sink abruptly to a depth of about 417 meters. The water temperature of this locality is $69^{\circ} \mathrm{C}$. This sudden variation in the depth of the limestone shows that the area is crossed by faults.

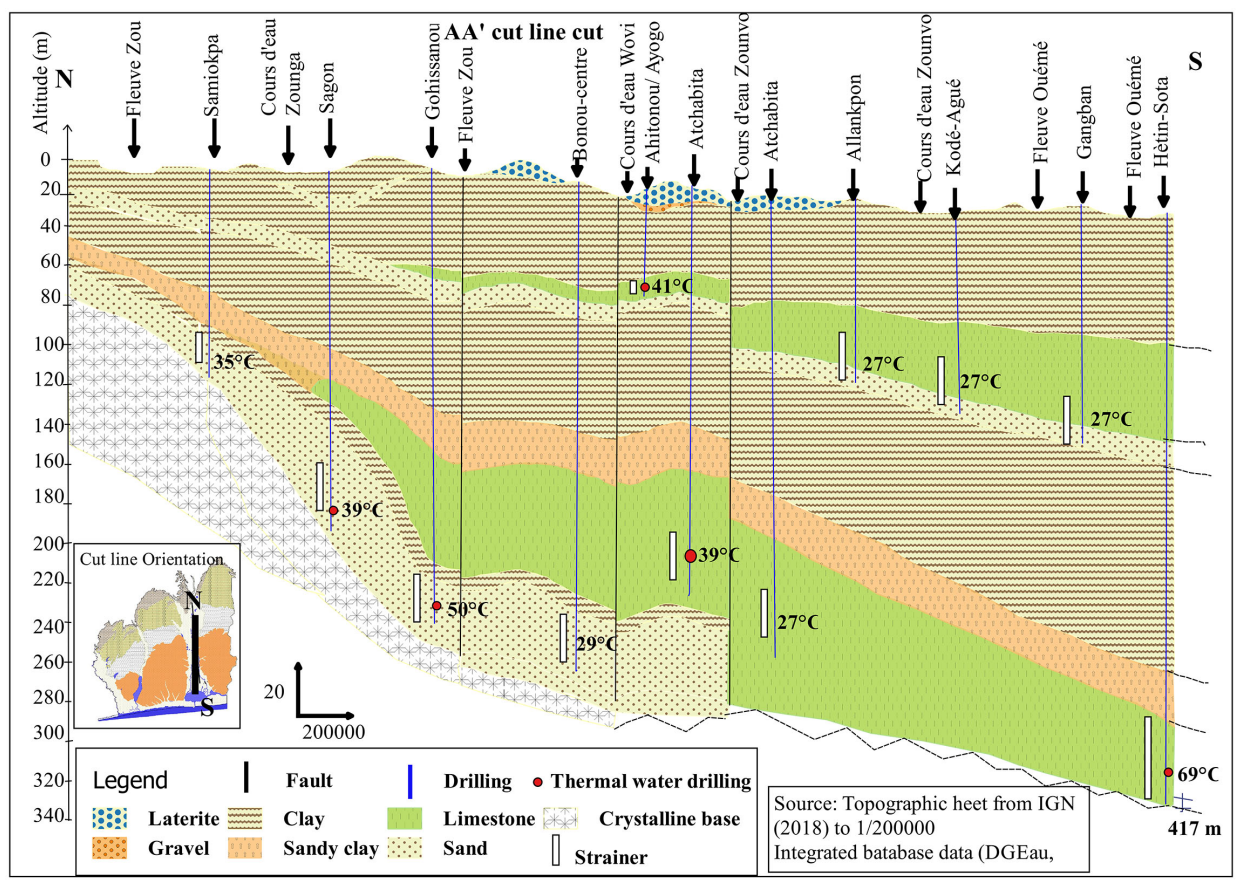

Figure 5. North-South hydrogeological cut following the AA' cut line. 
The N-S lithostratigraphic correlations of section BB' of the Couffo basin reveal seven types of facies in the studied area (Figure 6). They are from top to bottom clay, laterite or bar soil, gravel, clay sand, sand and gneiss. The summit formations are mostly represented by clays. There are a few levels of laterite sometimes. In the Northern part of the section, the localities of Affomai and Banigbe the clays have an average thickness of about 20 meters. Conversely, in the southern part of the section, from Adjame to the border of Possotomé, their thickness goes up to 140 meters with some layers of calcareous and marl levels. At the North of the section, the base is represented by the gneiss and located at about 70 meters depth. At the South of the section, in the localities of Agbodji, the sands subside to a depth of 300 meters while at five kilometers from these communities to the north of the section, the sands are located at an average depth of about 60 meters. The presence of Couffo and Ahémé lake streams in the proximity of the Possotomé and Eden thermal water boreholes $\left(55^{\circ} \mathrm{C}\right.$ and $50^{\circ} \mathrm{C}$ respectively) and the lags observed along the section suggest the presence of a fault system that was used to set them up.



Figure 6. North-South hydrogeological cut following BB' cut line.

\subsubsection{Depth of Aquifers Captured in the BSC}

Figure 7 shows the depth of the major aquifers in the coastal sedimentary basin. It is noticeable that the depth of aquifers increases from north to south. Indeed, the depth of the Cretaceous aquifer, which is about 40 meters in the northern 
zone where it outcrops, increases southwards to 280 meters under the outcrops of Paleogene marl and limestone of Lama Depression.

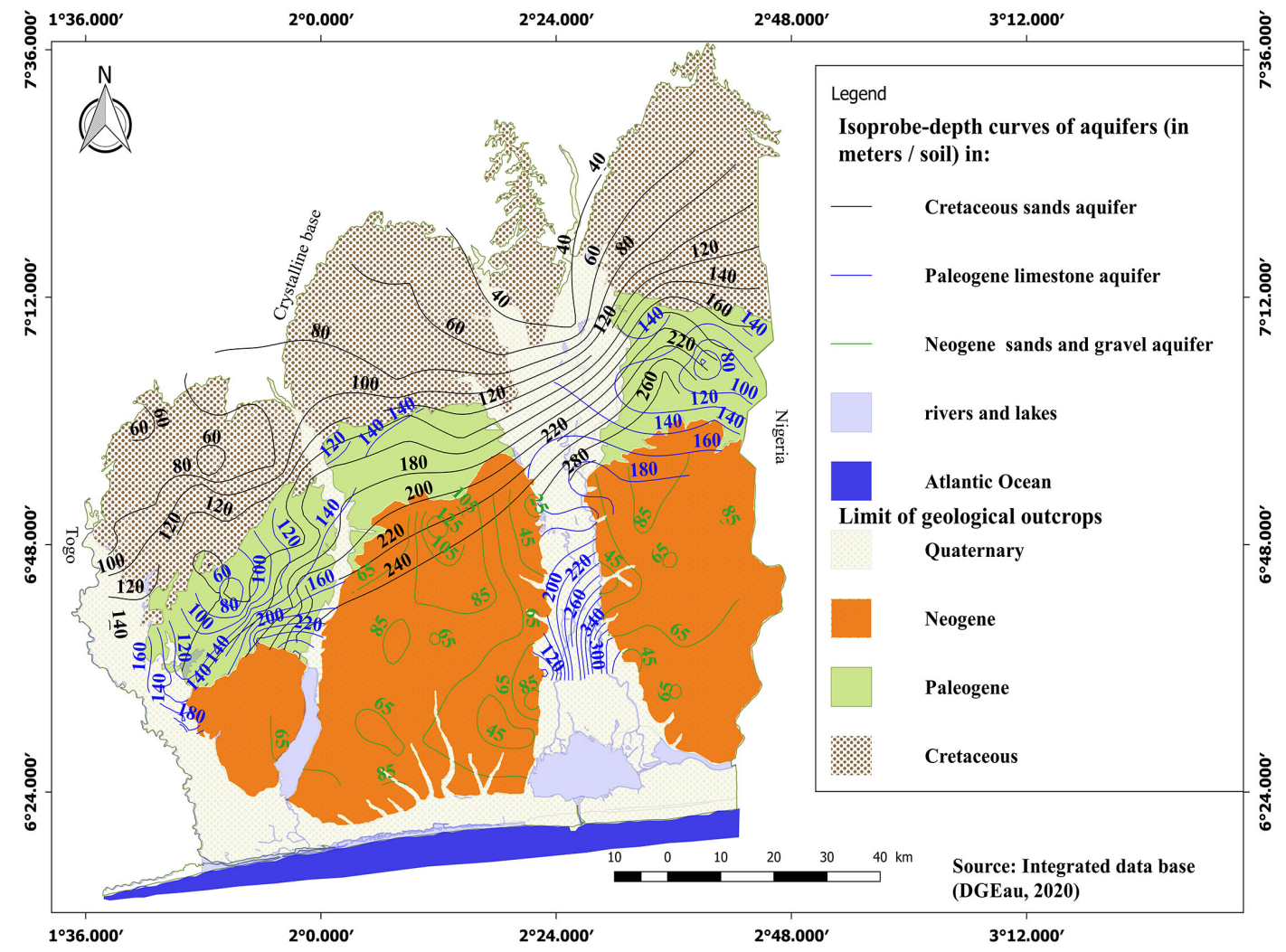

Figure 7. Aquifer depth map of the coastal sedimentary basin.

The Paleogene aquifer is 80 meters deep on average in the Lama depression, where it rises to 380 meters under the clays and marls of the valleys of the main BSC Rivers. The Neogene aquifer is captured on the southern plateaus of the BSC. The depth of this aquifer is 100 meters at the north and decreases to about 45 meters at the south of the plateaus.

\subsection{Thermal Variation of Aquifer Water in the BSC}

Figure 8 shows isotherm of water in the coastal sedimentary basin aquifers. The water temperatures of the major aquifers are noticed to be around 28 degrees Celsius to 34 degrees Celsius. Indeed, the temperature of the Cretaceous aquifer is about 29 degrees Celsius in the zone where it rises and $30-34$ degrees Celsius under the Paleogene clays and marls. The temperature of the Paleogene aquifer varies between 27 and 30 degrees Celsius. In the Neogene aquifer, trapped under the southern plateaus of the BSC, the water temperature is about 28 to 30 degrees Celsius.

Although the isotherms of the main aquifers are between 28 degrees Celsius and 34 degrees Celsius, some points in these aquifers have temperatures ranging from 38 to 69 degrees Celsius. These thermal anomalies are found in the valleys of the main rivers (Figure 8). 




Figure 8. Aquifer isotherm map of the coastal sedimentary basin.

\subsection{Distribution of $\mathrm{pH}$, Conductivity and Chemical Elements of BSC Thermal Waters}

\subsection{1. pH Variation of Thermal Waters}

Figure 9 illustrates the $\mathrm{pH}$ distribution of thermal waters in the Coastal Sedimentary of Benin. The thermal waters are found to be acidic in the north $(\mathrm{pH}$ between 4.8 and 5.5) and neutral to basic in the south ( $\mathrm{pH}$ between 7.3 and 8.5).

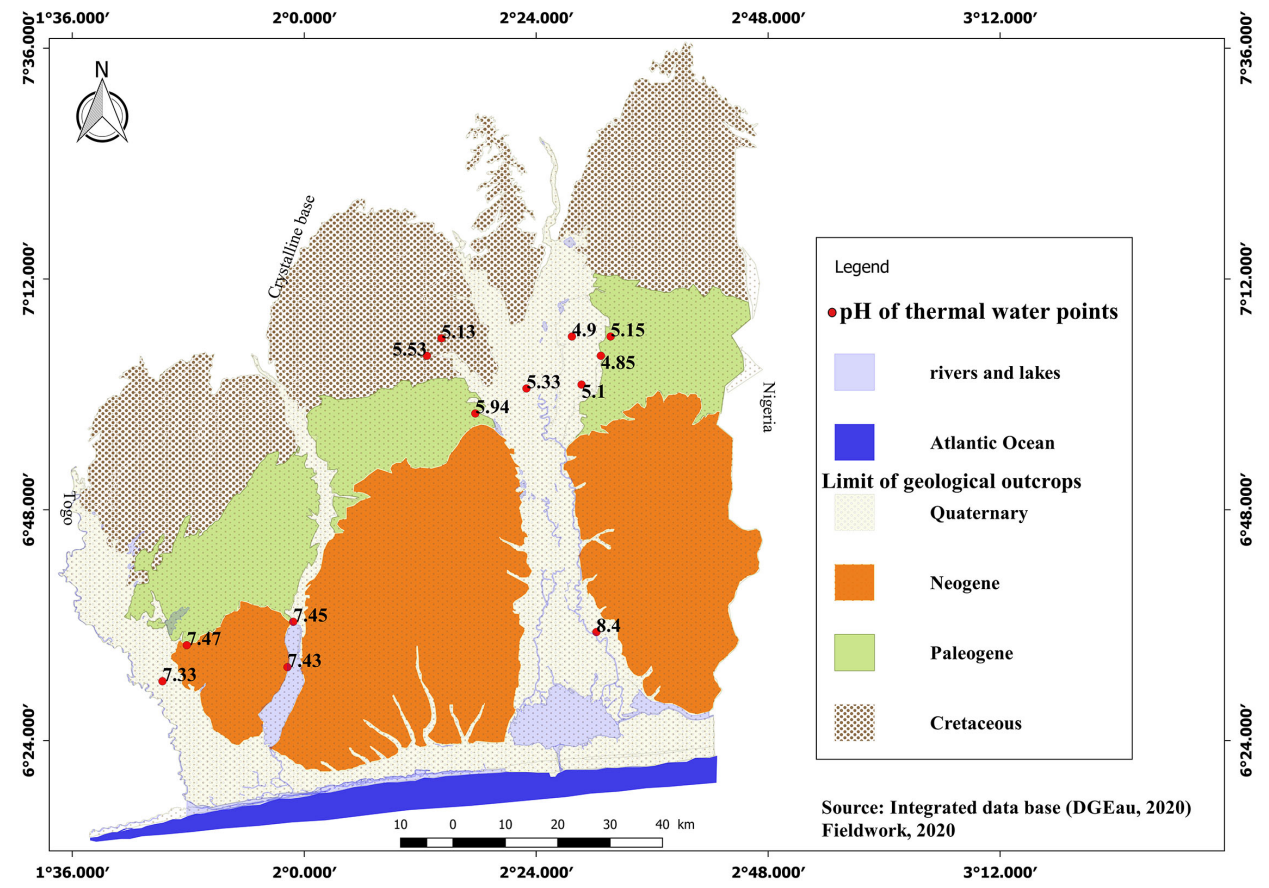

Figure 9. Distribution of thermal water boreholes and their $\mathrm{pH}$ in the BSC. 


\subsubsection{Composition in Bicarbonate, Calcium, Magnesium, Nitrate and Ammonium Ions in the Thermal Waters of the BSC}

The table below (Table 2) presents the physical and chemical characteristics of thermal waters of the coastal sedimentary basin of Benin. It is noted that bicarbonate ions have a high concentration in waters collected on the southern part of the BSC $(48.2 \mathrm{mg} / \mathrm{L}$ at $85.84 \mathrm{mg} / \mathrm{L})$. Bicarbonate ion concentration is high from $48 \mathrm{mg} / \mathrm{L}$ to $85 \mathrm{mg} / \mathrm{L}$ in the south and low from $8 \mathrm{mg} / \mathrm{L}$ to $39 \mathrm{mg} / \mathrm{L}$ in the North. Conversely, in the north of the BSC, calcium and magnesium have a high concentration in the collected thermal waters. The concentration in ion $\mathrm{Ca}^{2+}$ range from $6 \mathrm{mg} / \mathrm{L}$ to $13 \mathrm{mg} / \mathrm{L}$ with exceptionally high values at Gohissanou (47.17 mg/L), Kpokissa (57 mg/L) and Hetin-Sota $(64 \mathrm{mg} / \mathrm{L})$. On the other hand, the composition of $\mathrm{Mg}^{2+}$ changes from 5 to $22 \mathrm{mg} / \mathrm{L}$ with an exceptionally high value in Hètin-Sota $(78.86 \mathrm{mg} / \mathrm{L})$. The conductivity values of the captured thermal waters are raised from $940 \mu \mathrm{s} / \mathrm{cm}$ to $1850 \mu \mathrm{s} / \mathrm{cm}$ in the south and low from $154 \mu / \mathrm{cm}$ to $170 \mu \mathrm{s} / \mathrm{cm}$ to the north.

Table 2. The Physico-chemical elements of thermal waters.

\begin{tabular}{|c|c|c|c|c|c|c|c|c|}
\hline \multirow{2}{*}{\multicolumn{2}{|c|}{ Locality }} & \multicolumn{3}{|c|}{ Physics parameters } & \multicolumn{4}{|c|}{ Chemical parameters $(\mathrm{mg} / \mathrm{L})$} \\
\hline & & $\mathrm{EC}(\mu \mathrm{s} / \mathrm{cm})$ & $\mathrm{pH}$ & $\mathrm{T}\left({ }^{\circ} \mathrm{C}\right)$ & $\mathrm{HCO}_{3}^{-}$ & $\mathrm{Mg}^{2+}$ & $\mathrm{Ca}^{2+}$ & $\mathrm{NH}_{4}^{+}$ \\
\hline Hetin-Sota & & 1850 & 8.40 & 69 & 85.84 & 78.86 & 64.32 & 1.936 \\
\hline Agonsa & & 1146 & 7.45 & 52 & 56.12 & 6.97 & 10.72 & 0.710 \\
\hline Possotomé & $\begin{array}{c}\text { South of the } \\
\text { BSC }\end{array}$ & 1020 & 7.43 & 55 & 56.12 & 5.23 & 13.58 & 0.890 \\
\hline Eden & & 980 & 7.44 & 50 & 47.58 & 6.97 & 12.87 & 0.425 \\
\hline Allounkoui & & 940 & 7.55 & 40 & 48.2 & 6.97 & 9.27 & 1.347 \\
\hline Hon & & 170 & 5.94 & 52 & 39.04 & 22.66 & 6.64 & 0.087 \\
\hline Kpokissa & $\begin{array}{c}\text { North of the } \\
\text { BSC }\end{array}$ & 154 & 5.48 & 50 & 8.54 & 16.99 & 57.89 & $<0.001$ \\
\hline Gohissanou & & 162 & 5.54 & 50 & 10.98 & 17.86 & 47.17 & $<0.001$ \\
\hline
\end{tabular}

\section{Discussion}

From a geothermal and hydrogeological standpoint, the coastal sedimentary basin of Benin is characterized by thermal anomalies and artesian phenomena. Previous studies (Boukari \& Alassane, 2007) have shown that aquifers that are the object of artesian phenomena are those of Cretaceous and Paleocene. The mapping of thermal anomaly zones shows that thermal waters are particularly observed in certain points in the valleys of the main rivers on either side of the Lama depression. The origin of thermal variations seems more in relationship with tectonics.

According to Taillefer (2017), the process of groundwater warming occurs based on three origins. We can distinguish the magmatic hydrothermal systems (Faulds et al., 2010), derived from the heat released by magmatic bodies; hydrothermal systems of geothermal gradient type (Taillefer, 2017), (deep aquifers from 2000 meters to 3000 meters) and hydrothermal systems resulting from the rise of 
heat from the lithosphere through the faults (rise of the isotherms) (Trabelsi et al. (2007) and Taillefer (2017)). The main aquifers of the BSC do not reach a depth of 1000 meters, nor are they subject to any magmatic manifestation ... The valleys of the main rivers of the BSC are ditches that support tectonic manifestations (Dray et al., 1989). Geomorphology plays an important role in the distribution of hydrothermal systems (Drogue, 1985; Jilali et al., 2014; Zohra et al., 2011). Studies conducted by (IRB, 1989; Dray et al., 1989; Boukari \& Alassane, 2007) revealed deep faults system sedimentary portion of Benin. These structural factors play a key role in the genesis of thermal or mineral waters and serve as the basis for their classification (Risler, 1971). The warm water comes from the basement near the faults, which would diffuse a thermal and chemical anomaly in the aquifer (Danis et al., 1984). Studies conducted in the Great Basin in the USA, prove that hydrothermal systems are often linked to fragile faults and their origins are non-magmatic (Faulds et al., 2010).

The cross-sections made following the N-S directions reveal offsets in the geological layers which result in the thermal variation of the waters collected at Ahitonou (66 meters deep with a temperature of $41^{\circ} \mathrm{C}$ ) and Atchabita (deep 200 meters with a temperature of $27^{\circ} \mathrm{C}$ ). The continuous deformation zones are areas of weakness that serve as a channel for heat from the lithosphere and its distribution in nearby aquifers. Thus, the boreholes positioned in the areas of such phenomena will have a higher temperature compared to those in the vicinity. The random distribution of thermal water boreholes in the valleys of the main BSC streams is believed to be linked to tectonic events.

Since the chemical content of the waters is the result of the rocks crossed (Vernoux et al., 2014), the acidic behavior of the waters collected at the north of the BSC show that the northern part is under the influence of the basement. The aquifer captured to the north is from the sands of the Cretaceous which is made of major discordance at the base. On the contrary, in the South, the thermal waters have a neutral to basic $\mathrm{pH}$. The high concentration of bicarbonate ion in these waters shows that they originate in carbonate reservoirs. This higher mineralization is mainly related to a solution of Sulfate chlorides originating from attapulgite-type clay levels and sublittoral deposits containing carbonates, phosphates and sulphates (Dray et al., 1989).

Tectonic manifestations are believed to be the cause of the warming of the gushing aquifers waters.

\section{Conclusion}

In the coastal sedimentary basin in southern Benin, the water of gushing aquifers captured in the valleys of major rivers has high temperatures, especially in some localities. These aquifers are made up of sands with an acid $\mathrm{pH}$ influenced by the crystalline base underlying the north, and limestone, then marl with a neutral or basic $\mathrm{pH}$ to the south. Clearly, the artesian phenomena of the aquifers of the valleys of the major streams are closely related to the topography which is a factor 
controlling their piezometry. The thermal water boreholes irregularly distributed among all the water boreholes gushing from the river valleys are said to be related to fault crossings. However, this hypothesis remains to be elucidated by our forthcoming linear studies, sedimentological and geochemical.

\section{Conflicts of Interest}

The authors declare no conflicts of interest regarding the publication of this paper.

\section{References}

Adissin, G. L., Alassane, A., Dossou, P. M., Zogo, A., Ahossi, A., \& Gbéwezoun, V. (2019). Influence de la réactivation de la faille de Kandi sur le phénomène de l'artésianisme dans le bassin versant du fleuve Mono au Sud-Ouest du bassin sédimentaire côtier du Bénin (Afrique de l'Ouest). European Scientific Journal, 15, 403-424.

Ahossi, M. A. (2020). Vulnérabilité du Crétacé supérieur à la variabilité climatique et aux activités anthropiques dans le bassin versant du Mono à l'exutoire de Athiémé au Bénin. thèse de doctorat de l'Université d'Abomey-calavi, Géosciences de l'environnement et aménagement de l'espace.

Boukari, M. (2002). Réactualisation des connaissances hydrogéologiques relatives, relatives au bassin sédimentaire côtier du Benin (137 p). Direction de l'hydraulique.

Boukari, M. (2005). Aquifères côtiers de l'Afrique de l'Ouest (Bénin, Nigéria, Togo, Ghana, Cote d'ivoire), rapport de l'atelier national sur le document de projet regional a moyen terme, document-guide (62 p).

Boukari, M., \& Alassane, A. (2007). Les ressources en eau souterraine du bassin sédimentaire côtier de la république du Bénin. Africa Géoscience Review, 14, 283-301.

Danis, M., Royer, J., \& Demassieux (1984). Interprétation d'une anomalie géothermique et géochimique dans la région de Vittel-Contrexéville (pp. 305-315). Travaux de centre de recherche pétrographique et géochimique, Hydrogéologie-géologie de l'ingénieur.

Dray, M., Giachello, L., Lazzarotto, V., Mancini, M., Roman, E., \& Zuppi, G. M. (1989). Etude isotopique de l'aquifère Crétacé du bassin sédimentaire côtier béninois.

Drogue, C. (1985). Geothermal Gradients and Ground Water Circulation in Fissured and Karstic Rocks: The Role Played by the Structure of the Permeable Network. Journal of Geodynamics, 4, 219-231. https://doi.org/10.1016/0264-3707(85)90061-4

Faulds, J., Coolbaugh, M., Vice, G., \& Edward, M. (2010). Characterizing Structural Controls of Geothermal Fields in the Northwestern Great Basin: A Progress Report. GRC Transaction, 30, 2006.

IEA (2011). Technology Roadmap, Geothermal Heat and Power (67 p). International Energy Agency. https://webstore.iea.org/technology-roadmap-geothermal-heat-and-power

IRB Institut de Recherche Breda (1989). Notice explicative de la carte géologique à 1/200000, Feuille Pira-Savè, Abomey-Zagnanado et Lokossa-Porto Novo, mémoire $n^{\circ} 3$, 1ere édition (77 p).

Jilali, A., Rimi, A., Zarhloule, Y., Ouzzaouit, L., Barkaoui, A., Antonio, C., \& Carneiro, J. (2014). Structure hydrogéothermique de la région Figuig (Haut Atlas oriental, Maroc). Bulletin de I'Institut Scientifique, Rabat, Section Sciences de la Terre, 36, 123-134.

Kapasa, C. (2014). Evaluation of Current and Feasible Future Use of Geothermal Energy at Chinyunyu Hot Spring, Zambia. KTH School of Industrial Engineering and Management Department of Energy Technology, EGI-2014-038MSC-EKV1026 Division of 
Heat and Power Technology SE-100 44 STOCKHOLM.

Lang, J., \& Houessou, A. (1978). Contribution à l'étude du continental terminal terminal dans le Bénin méridional. Bulletin des sciences géologique, 31, 137-149.

Lawin, E. (2007). Analyse climatologique et statistique du régime pluviométrique de la haute vallée de l'Ouémé à partir des données pluviographiques, AMMA-CATCH Benin (231 p). Thèse de doctorat préparée conjointement au laboratoire de transferts en hydrologie et environnement et la chaire internationale en physique mathématique et application.

Le Barbé, L., Ale, G., Millet, B., Taxier, H., Borel, Y., \& Gualde, R. (1993). Les ressources en eau superficielle de la République du Bénin. Institut français de recherche scientifique pour le développement en coopération: Collections Monographies Hydrologiques $\mathrm{n}^{\circ} 11$.

Moriasi, D. N., Arnold, J. G., Van Liew, M. W., Bingner, R. L., Harmel, R. D., \& Veith, T. L. (2007). Model Evaluation Guidelines for Systematical Quantification of Accuracy in Watershed Simulations. Transactions of the ASAE, 50, 885-900. https://doi.org/10.13031/2013.23153

Oyede, L. M., Tossou, M. G., Kaki, C., Laibi, R. A., \& Lang, J. (2006). Phénomènes enregistrables, milieu enregistreur et messages enregistrés: Application aux séquences biosédimentaires du quaternaire récent dans le géosystème margino-littoral béninois (Afrique de l'Ouest). Africa Géoscience Review, 13, 395-408.

Risler, J. (1971). Description et classification géologique des sources minérales et thermales du massif central. BRGM, Service des eaux minérales et thermales.

Slansky, M. (1962). Contribution à l'étude géologique du bassin sédimentaire côtier du Danhomey et du Togo. Mémoire du Bureau recherche géologique et minière.

Taillefer, A. (2017). Interactions entre tectonique et hydrothermalisme: Rôle de la faille normale de la Têt sur la circulation hydrothermale et la distribution des sources thermales des Pyrénées Orientales (250 p). Thèse de doctorat de l'Université de Montpellier, spécialité: Sciences de la terre. https://tel.archives-ouvertes.fr/tel-01704673

Trabelsi, S., Bouri, S., \& Ben Dhia, H. (2007). Contribution des approches hydrochimiques et géothermométriques à l'étude des eaux thermales de la province fluorée tunisienne (Nord-Est Tunisien). Revue des Energies Renouvelables CER'07, Oujda, 85-88.

Vernoux, J. F., Wuilleumier, A., \& Perrin, J. (2014). Délimitation des aires d'alimentation des captages d'eau souterraine et de leur vulnérabilité vis-à-vis des pollutions diffuses (133 p). Rapport BRGM-63331-FR.

Zevounou, C. (1992). Géologie, quelques questions de biostratigraphie et de phosphatogenèse des formations Cénozoïques de la Baie du Bénin. Thèse de doctorat de l'Université Russe de l'amitié des peuples de moscou, Géologie et prospection des minéraux utiles.

Zevounou, C., Kaki, C., Laibi, R. A., \& Oyede, L. M. (2012). Caractéristiques pétro-stratigraphiques et conditions de genèse des phosphates dans le bassin sédimentaire côtier du Bénin (Golf du Bénin). Africa Géoscience Review, 19, 59-67.

Zohra, F., Haouchine, B., Boudoukha, A., \& Haouchine, A. (2011). Hydrogéochimie et géothermométrie: Apports à l'identification du réservoir thermal des sources de hammam righa, algérie. Hydrological Sciences Journal, 57, 1184-1195.

https://www.tandfonline.com/loi/thsj20

https://doi.org/10.1080/02626667.2012.694448 